\title{
In the pursuit of indexing
}

\author{
Aloisio Felipe-Silva ${ }^{a}$
}

Felipe-Silva A. In the pursuit of indexing [editorial]. Autopsy Case Rep [Internet]. 2012;2(4):1-3. http://dx.doi.org/ 10.4322/acr.2012.028

The world, the science and the ways of communication have changed rapidly after the popularization of the Internet. The medical autopsy, an almost handmade procedure that has been in practice for teaching and research for centuries, needs to renew or reinvent itself in order to continue to demonstrate its known academic and scientific value in the twenty-first century.

Autopsy and Case Reports is an electronic publication that was born in this context, inspired by weekly autopsy conferences presented at the Department of Pathology of the Hospital Universitario - Universidade de São Paulo (Brazil). At these meetings, clinicians, pathologists, surgeons, medical residents, and students learn information based on the correlation between the clinical, radiological, and pathological findings of the autopsies. This type of conference has been a core of medical education for centuries, and largely overlaps with its history. However, autopsy conferences (or anatomoclinical sessions) have been losing ground in the global medical education field either because of the dramatic reduction in the number of academic autopsies $^{1,2}$ or the uncritical belief in the infallibility of imaging methods. Systematically, and supported by the literature, ${ }^{3,4}$ autopsy discrepancy rates are still significant today. Even in concordant cases, integrated learning has immeasurable value.

Despite providing plenty of useful and high-quality information, the analytical approach of autopsy cases is rare in contemporary medical literature. The articles, particularly case reports, are extremely succint in their analytical potential. ${ }^{5}$
We took the initiative to spread this approach to the scientific community and, above all, we have been calling other partner services that share this vision to contribute with well-documented cases, which, like ours, may be useful to the reader.

The global decline in the number of academic autopsies is remarkable. This editorial board struggles against a potential practical extinction of the academic autopsy as we know it. We do believe that the teachings from autopsies are still important for graduates in the health sciences, especially for the medical students. The analytical approach of autopsy cases provides the opportunity to learn and to "see" the pathophysiology of important diseases as a whole and "real" process and not only a matter in the field of imagination. It is also a valuable exercise in the correlation of imaging findings with gross anatomical specimens. The autopsy conferences and case reports are also intended to be a tool for quality control of medical care since they allow the discussion of diagnostic discrepancies and the building of medical reasoning.

We were not able to find any other journal with this focus on autopsy case reports in databases from Brazil and Latin America. Even in the PubMed database we could not find a specialized periodical with this approach. Of note, the Revista Electronica de la Autopsia (ISSN 1699-2334), an electronic Spanish journal edited between 2003 and 2011, was the single specialized journal we could find in this field. Of course, there are many autopsy case reports dispersed in pathology and clinical journals elsewhere.

a Hospital Universitário - Universidade de São Paulo, São Paulo/SP - Brazil.

Copyright (c) 2012 Autopsy and Case Reports - This is an Open Access article distributed of terms of the Creative Commons Attribution NonCommercial License (http://creativecommons.org/licenses/by/3.0/) which permits unrestricted non-commercial use, distribution, and reproduction in any médium provided article is properly cited. 
Autopsy and Case Reports is currently indexed in databases to open access and electronic journals such as Sumários de Revistas Brasileiras (sumarios.org) and Sistema Regional de Información en Línea para Revistas Científicas de America Latina, el Caribe, España e Portugal (Latindex). One of the issues about indexing in major databases is the need for a high number of articles in the "original articles" category, which include original research and systematic reviewsbut not case reports.

Many case reports published in Autopsy and Case Reports to date are accompanied by a literature review, providing the reader with an update on the issue at hand. Examples include the articles "Hemophagocytic lymphohistiocytosis of indeterminate cause: a fatal adult case," 6 and "Spindle-cell carcinoma of the prostate." Although they do not have the obvious subtitle "case report and review of the literature," they are, in fact, practical review articles, and could be classified as original articles according to current criteria. From the standpoint of an editor, here is the dilemma: should a systematic review in a case report be mandatory? Otherwise, could a journal based on traditional case reports be indexed in major databases?

At this point we should consider, again, the purpose and the proposal of Autopsy and Case Reports, despite the systematic literature reviews: the teaching and dissemination of knowledge (common to most scientific journals) through case reports (this is, in fact, a peculiarity of a few journals). Notably when it comes to the scarce and "dying" art of academic autopsy ${ }^{1}$, any welldocumented case report duly submitted to the scrutiny of the peer review process becomes part of a common or "planetary" database in the Internet era. Case reports, especially taken collectively, are of great value not only in the spread, but also in the sedimentation of medical knowledge, and contribute significantly to the progress of science. ${ }^{8}$ The experience of "reading a real case" brings important learning. An example of this was exposed by Dr. Robert Anderson (England), a specialist and world reference in congenital heart diseases, who graced us with the editorial, "Is an interatrial communication the same as an atrial septal defect?" inspired by the article, "An inferior sinus venosus interatrial communication associated with a secundum atrial septal defect, clinically presenting in an adult patient: autopsy report."10
It is worth noting that some publications specializing in case reports are indexed in Medline: BMJ Case Reports - ISSN: 1757-790X (electronic); Journal of Radiology Case Reports - ISSN: 19430922 (electronic); Pediatric Case Reviews - ISSN: 1533-0664 (electronic), among others. And there are others that, although not indexed, follow the same principle: Case Reports in Obstetrics and Gynecology [electronic resource]-ISSN: 2090-6692 (electronic); Case Reports in Pediatrics [electronic resource] - ISSN: $2090-6811$ (electronic). It is no coincidence that many of these journals began fairly recently (in the 2000's) and are in electronic format, which conveys this spirit of information disclosure with the ease of the Internet. Autopsy and Case Reports belongs to this new generation of journals, but with a unique proposition in terms of focus, scope, and approach.

We have the prospect of increasing the number of articles per issue, as well as engaging other departments and centers since a larger number of original papers and a reasonable level of intramural articles are important criteria for major database indexing. But we're still new and therefore unfamiliar, and struggle to receive submissions that address the scope we have set for this journal. We believe that in the near future we can achieve greater visibility within Brazil, Latin America, and the world medical community -in an attempt to show the enormous importance and current value of the autopsy in enhancing the quality of medical care, and in generating knowledge and education. This issue of Autopsy and Case Reports (December 2012) marks a two-year period of uninterrupted publication. We think that indexing databases should be aware of this current, contemporary, and innovative view of case reports journals. Indexing criteria should be revised on occasion to make room for the inclusion of case reports journals in major databases.

\section{REFERENCES}

1. Shojania KG, Burton EC. The vanishing nonforensic autopsy. N Engl J Med. 2008;358(9):873-5. PMid:18305264. http:// dx.doi.org/10.1056/NEJMp0707996

2. Xiao J, Krueger GR, Buja LM, Covinsky M. The impact of declining clinical autopsy: need for revised healthcare policy. Am J Med Sci. 2009;337(1):41-6. PMid:19155753. http:// dx.doi.org/10.1097/MAJ.0b013e318184ce2b

3. Winters B, Custer J, Galvagno SM, et al. Diagnostic errors in the intensive care unit: a systematic review of autopsy 
studies. BMJ Qual Saf. 2012;21(11):894-902. PMid:22822241. http://dx.doi.org/10.1136/bmjqs-2012-000803

4. Wichmann D, Obbelode F, Vogel H, et al. Virtual autopsy as an alternative to traditional medical autopsy in the intensive care unit: a prospective cohort study. Ann Intern Med. 2012;156(2):123-30. PMid:22250143.

5. Campos FPF. What does the future hold? [editorial]. Autopsy Case Rep. 2012;2(1):3-5. http://dx.doi.org/10.4322/ acr.2012.001

6. Campos FPF, Lima PP, Lima FR, et al. Hemophagocytic lymphohistiocytosis of indeterminate cause: a fatal adult case. Autopsy Case Rep. 2012;2(2):11-20. http://dx.doi. org/10.4322/acr.2012.011
7. Silva CHW, Rojas Claros O, Amselem I, Sá Filho NS, Fugita $\mathrm{OEH}$. Spindle-cell carcinoma of the prostate. Autopsy Case Rep. 2012;2(1):55-61. http://dx.doi.org/10.4322/acr.2012.009

8. Campos FPF. Sharing experience through case reports [editorial]. Autopsy Case Rep. 2012;2(2):1-3. http://dx.doi. org/10.4322/acr.2012.010

9. Anderson $\mathrm{RH}$. Is an interatrial communication the same as an atrial septal defect? [editorial]. Autopsy Case Rep. 2011;1(4):1-2. http://dx.doi.org/10.4322/acr.2011.010

10. Lovisolo SM, Campos FPF, Aiello VD. An inferior sinus venosus interatrial communication associated with a secundum atrial septal defect, clinically presenting in an adult patient: autopsy report. Autopsy Case Rep. 2011;1(4):21-27. http://dx.doi.org/10.4322/acr.2011.013

Correspondence: Aloisio Felipe-Silva

Scientific Editor Autopsy and Case Reports

Assistant Physician of Anatomic Pathology Service

Hospital Universitário - Universidade de São Paulo, São Paulo/SP - Brazil

E-mail: aloisiosilva@hu.usp.br 
